\title{
Low right ventricular endocardial potentials in chronic Chagas' disease
}

\author{
Orlando Gurdiel, Alberto París, Cesar Alemán, Manuel Penso, José Gordo, and Alan Harris \\ From the Cardiac and Pathological Departments of Dr. Miguel Perez Carreño Hospital, Caracas, Venezuela
}

Right ventricular endocardial potentials were measured in 20 patients with Chagas' disease of the heart and compared with the right ventricular endocardial potential in 20 patients with chronic heart block from other causes.

The average right ventricular endocardial potential in patients with Chagas' disease was much lower than the right ventricular endocardial potential in patients with chronic heart block from other causes. There is a highly significant difference $(0.001<P<0.005, t$-test) between the mean right ventricular endocardial potentials in the two groups of patients studied.

The low right endocardial potential in patients with Chagas' disease of the heart was related to the histological evidence of extensive cardiac muscle destruction.

Low endocardial potentials have been recorded in the right ventricle in patients with acute myocardial infarcts (Chatterjee et al., 1970; Chatterjee and Rouse, I97I) and massive pulmonary embolism (Chatterjee, Sutton, and Miller, 1972).

It seemed possible that low endocardial potentials were caused by serious myocardial damage which could be reversible as in ischaemic heart disease, pulmonary embolism, and septicaemic shock. Since Chagas' disease involving the heart produces widespread damage to myocardial fibres, endocardial potentials have been studied in a group of patients with chronic Chagas' disease of the heart.

\section{Subjects and methods}

Forty patients with Adams-Stokes attacks were studied. Twenty had typical chronic Chagas' disease. This was based on the epidemiological background, clinical and electrocardiographic evidence compatible with that observed in chronic Chagas' disease, and a positive complement-fixation reaction (Chagas' test) for $S$. cruzi which is a specific reaction for Chagas' disease (Maekelt, 1960). The 20 remaining patients were without an epidemiological background and were Chagas' test negative. All the patients had permanent pacing systems installed for the treatment of their chronic heart block and the endocardial potential measurements were made at the time of implantation of a permanent pacing system.

After making sure that the pacing wire electrode was well placed in the apical region of the right ventricle, we recorded the endocardial electrocardiograms by conRecieved I3 May I974. necting the tip of the electrode catheter to the ' $V$ ' lead of a direct writing electrocardiograph recording at a paper speed of $25 \mathrm{~mm} / \mathrm{sec}$. Following the same criterion as Chatterjee et al. (1972), we measured the amplitude of the total deflection of the QRS in millivolts and the mean from ro complexes showing the typical ST segment elevation (Levine et al., 1949; Gordon, Vagueiro, and Barold, 1968; Evans and Glasser, 197I).

The values of the endocardial potentials of the group with chronic Chagas' disease were compared with the group with Chagas' test negative. We excluded patients with acute myocardial infarction who often have low endocardial potentials (Chatterjee et al., 1970).

In Table I (patients with Chagas' test positive) the average age was 57.3 years with a range of 34 to 74 years. There were 13 women and 7 men. The average of the right ventricular endocardial potential was $4.32 \pm$ 2.01 $\mathrm{mV}$ (range 2.15 to $9.05 \mathrm{mV}$ ).

In Table 2 (patients with Chagas' test negative) the average age was 60.9 years with a range of 34 to 89 years. There were 15 women and 5 men. The average of the right ventricular endocardial potentials was $7.78 \pm 3.95 \mathrm{mV}$ (range 2.43 to $15.7 \mathrm{I} \mathrm{mV}$ ). There is a highly significant difference $(0.001<P<0.005$, t-test) between the mean right ventricular endocardial potentials in the two groups of patients studied.

The typical right ventricular endocardial potential is shown in Fig. I. The upper graph shows a patient from group 2 with Chagas' test negative and the lower graph a patient from group I with Chagas' test positive.

Five patients died. Three belonged to group I (Chagas' test positive) and 2 were from group 2 (Chagas' test negative). Necropsy was performed in 2 patients - I from each group. 
TABLE I Patients in heart block with Chagas' test positive

\begin{tabular}{|c|c|c|c|}
\hline Case No. & $A g e(y r)$ & Sex & $\begin{array}{l}\text { Right ventricle } \\
\text { endocardial potential } \\
\text { (mean in } m V \text { ) }\end{array}$ \\
\hline I & 74 & $\mathbf{M}$ & $2 \cdot 15$ \\
\hline 2 & 62 & $\mathbf{M}$ & $3 \cdot 7 \mathrm{I}$ \\
\hline 3 & 57 & F & $3 \cdot 20$ \\
\hline 4 & 73 & $\mathbf{M}$ & 3.00 \\
\hline 5 & $6 \mathrm{I}$ & $\mathbf{F}$ & 3.43 \\
\hline 6 & 60 & $\mathbf{F}$ & $4 \cdot 87$ \\
\hline 7 & 64 & $\mathbf{F}$ & $2 \cdot 34$ \\
\hline 8 & 53 & F & 8.68 \\
\hline 9 & $5 I$ & F & $5 \cdot 26$ \\
\hline 10 & 70 & F & $3 \cdot 20$ \\
\hline II & 65 & $\mathbf{M}$ & $6 \cdot 42$ \\
\hline 12 & 53 & $\mathrm{~F}$ & 2.92 \\
\hline 13 & 34 & $\mathbf{M}$ & 5.67 \\
\hline 14 & 48 & $\mathrm{~F}$ & $2 \cdot 37$ \\
\hline 15 & 38 & $F$ & 9.05 \\
\hline 16 & 56 & $\mathbf{M}$ & 3.90 \\
\hline 17 & 62 & F & 3.72 \\
\hline 18 & 53 & F & 3.47 \\
\hline $\begin{array}{l}191 \\
20\end{array}$ & $\begin{array}{l}58 \\
54\end{array}$ & $\begin{array}{l}\mathrm{M} \\
\mathrm{F}\end{array}$ & $\begin{array}{l}6.90 \\
2 \cdot 16\end{array}$ \\
\hline 20 & 54 & $\mathbf{F}$ & 2.10 \\
\hline
\end{tabular}

TABLE 2 Patients in heart block with Chagas' test negative

\begin{tabular}{lllr}
\hline Case No. & Age $(y r)$ & Sex & $\begin{array}{r}\text { Right ventricle } \\
\text { endocardial potential } \\
\text { (mean in mV) }\end{array}$ \\
\hline 2 I & 62 & F & 6.92 \\
22 & 77 & M & 6.99 \\
23 & 50 & F & 12.57 \\
24 & 61 & F & 2.56 \\
25 & 50 & F & 5.73 \\
26 & 70 & F & 3.58 \\
27 & 74 & F & 13.00 \\
28 & 34 & F & 6.23 \\
29 & 52 & F & 2.43 \\
30 & 50 & F & 4.46 \\
31 & 65 & F & 9.86 \\
32 & 48 & M & 3.06 \\
33 & 89 & F & 10.35 \\
34 & 65 & M & 8.53 \\
35 & 58 & M & 2.73 \\
36 & 73 & F & 15.71 \\
37 & 40 & F & 6.23 \\
38 & 69 & F & 10.43 \\
39 & 60 & F & 11.87 \\
40 & 72 & M & 12.42 \\
\hline & & & \\
\hline
\end{tabular}
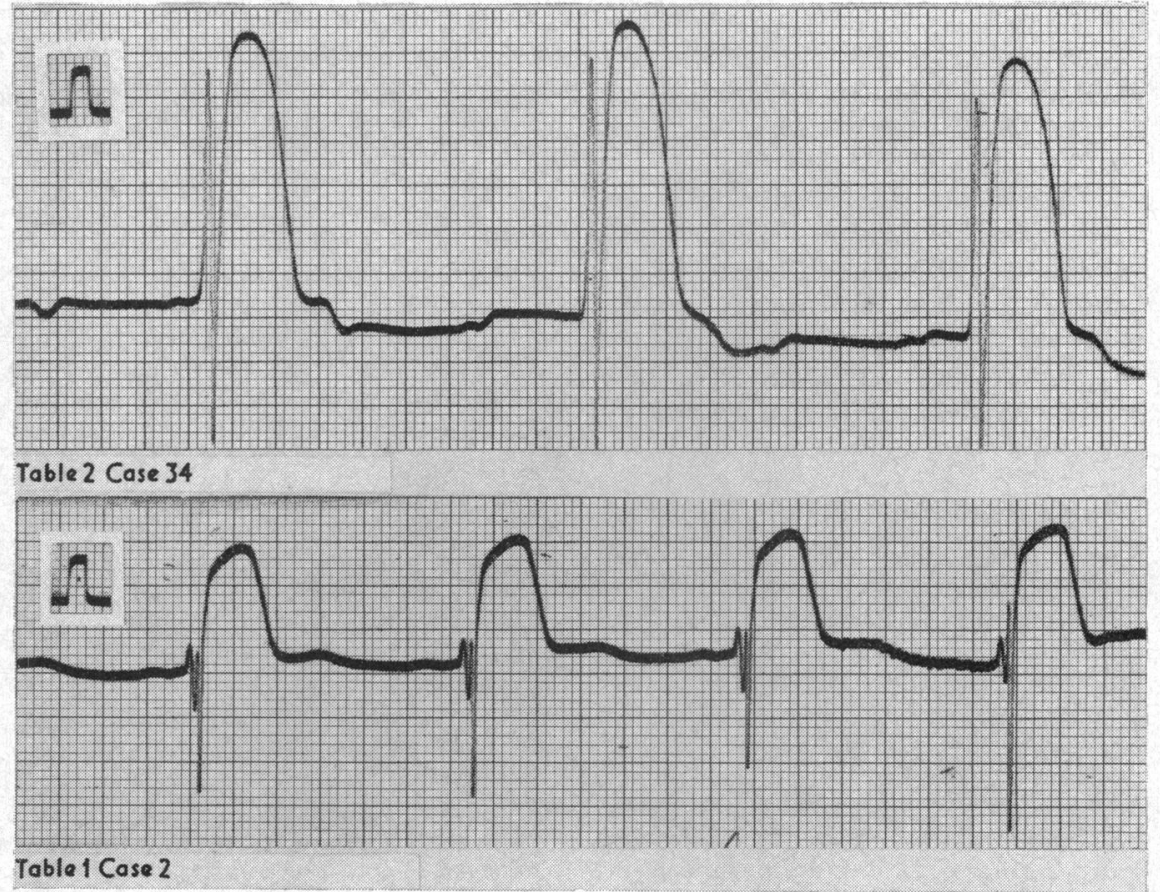

FIG. I Endocardial potentials recorded from the electrode tip placed on the endocardium of the right ventricle. The upper graph is from Case 34 (Table 2) (Chagas' test negative) with an average endocardial potential of $8.53 \mathrm{mV}$. The lower graph is of Case 2 (Table I) (Chagas' test positive) with an average endocardial potential of $3.71 \mathrm{mV}$. In the upper left corner of each graph the standardization signal is shown $(\mathrm{I} \mathrm{mV}=0.5 \mathrm{~cm})$. 


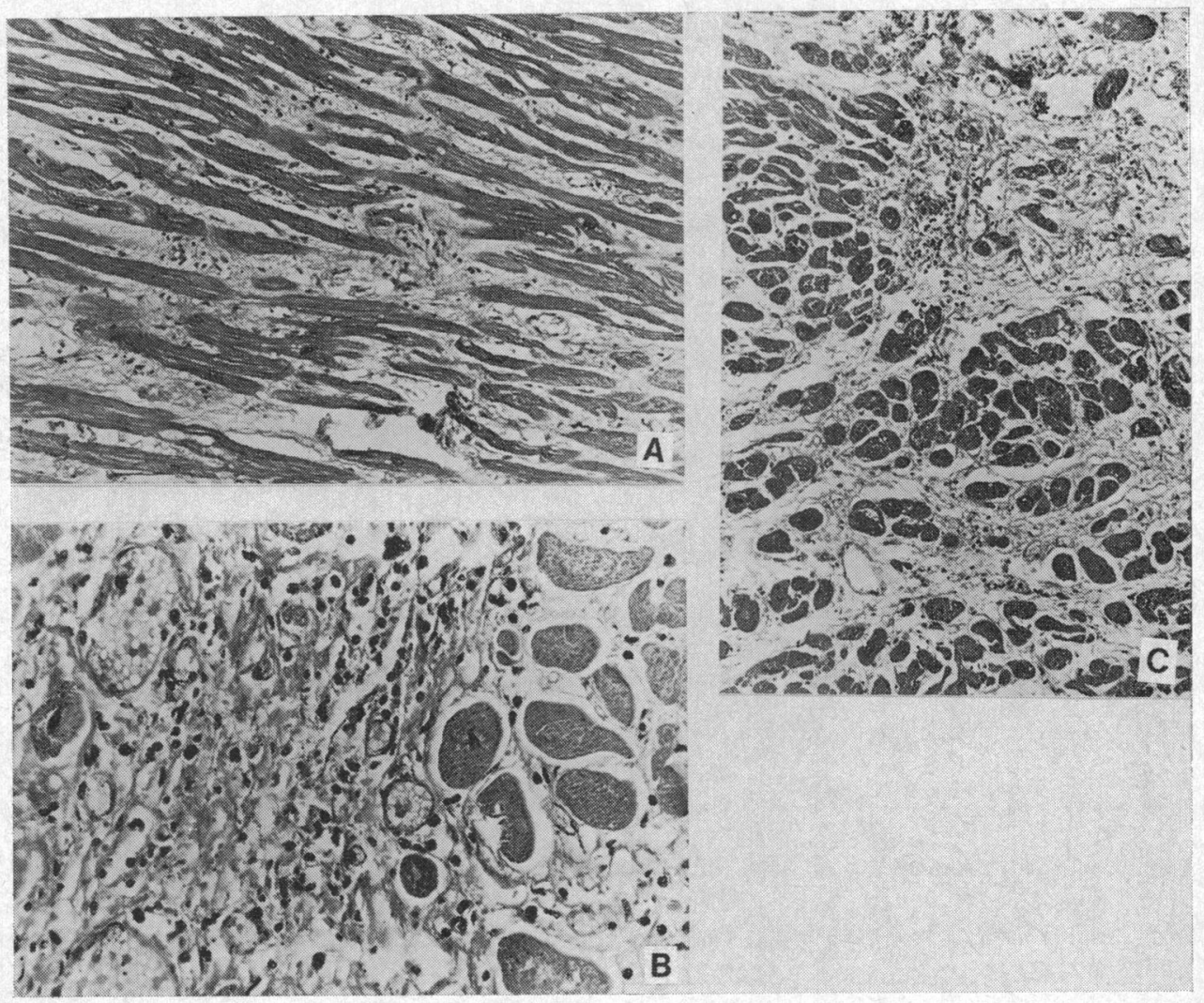

FIG. 2 Case 3 (Table I). The microscopical section of the heart revealed: A) Myocardium with fragmentation and destruction of fibres. Interstitial fibrosis and centres of infiltration with round cells. (Haematoxylin and eosin. $\times 25$.) B) Centres of myocardial cell destruction with fibrosis and inflammatory infiltration by round cells. (Haematoxylin and eosin. $\times 62$.) C) Myocardium with focal infiltration by round cells, interstitial fibrosis, and oedema. (Haematoxylin and eosin. $\times 25$.

The heart at the necropsy on Case 3 (Table I), with Chagas' test positive, weighed $450 \mathrm{~g}$. It was flaccid, and showed dilatation of all four cavities. The left ventricular muscle was notably thin at the apex; the valvular apparatus and coronary arteries were normal. Microscopical study revealed (Fig. 2) interstitial fibrosis of variable grade with an infiltration of both round and polynuclear inflammatory cells. The myocardial cells showed central destruction and fragmentation, with loss of myocardial fibres.

In the necropsy performed on Case 32 (Table 2) with Chagas' test negative, we found the heart flaccid, weight $430 \mathrm{~g}$. The right ventricular wall was hypertrophied. There was no disease of the valve apparatus. The coronary arteries showed atheromatous degeneration - but without significant narrowing. The microscopical examination (see Fig. 3) of the heart muscle showed nuclear pleomorphism with signs of hypertrophy of the myocardial fibres, as well as destruction of the fibres and interstitial fibrosis.

\section{Discussion}

The average QRS amplitude recorded in the apex of the right ventricle in the group of patients with Chagas' test positive (Table I - chronic Chagas' disease) was much lower than the average of the other group of patients with heart block and Chagas' test negative (Table 2). However, in both groups there were patients with normal endocardial potentials.

If we relate the low endocardial potential to the histological evidence of muscle destruction, then perhaps the endocardial potential reflects the number of surviving myocardial cells. The endocardial potential recorded in the right ventricle is the result of the sum of the potentials generated as each myocardial cell is depolarized. The amplitude of the endocardial potential will be inversely proportional to the number of destroyed myocardial 
cells whether or not replaced by fibrous tissue as in acute myocardial infarction (Chatterjee et al., 1970) or with chronic destruction of muscle as in severe ischaemic heart disease, where fragmented myocardial fibres and diffuse interstitial fibrosis can be seen (Fig. 3, Case 32, Table 2) and low endocardial potentials recorded.

In chronic Chagas' disease, where centres of myocytolysis were found in an isolated form, with fragmentation and loss of fibres (Fig. 2, Case 3, Table I) low endocardial potentials were recorded. Involvement of the myocardium by Chagas' disease produces progressive destruction of myocardial cells; thus, depending on the number of cells destroyed, so the endocardial potential is diminished. For this reason, we have found in our study patients with normal average figures, others slightly diminished, and others with extremely low potentials.
In addition, the myocardium involved by chronic Chagas' disease shows not only destruction of myocardial cells, but is also characterized by infiltrated centres of round and polymorphonuclear inflammatory cells (Anselmi et al., I966) which may reduce the endocardial potential arising from surviving healthy cells (Fig. 2).

Other acute conditions, however, can diminish endocardial potentials of the right ventricle, without there having been destruction of myocardial fibres. For example, Case 29 (Table 2), when in septicaemic shock, had very low right ventricular endocardial potential which returned to normal when the patient recovered.

\section{References}

Anselmi, A., Pifano, F., Suarez, J. A., and Gurdiel, O. (1966). Myocardiopathy in Chagas' disease. I. Comparative study of pathologic findings in chronic human and experimental Chagas' myocarditis. American Heart fournal, 72, 469. 
Chatterjee, K., Davies, G., Harris, A., and Leatham, A. (1970). Fall of endocardial potentials after acute myocardial infarction. Lancet, I, 1308.

Chatterjee, K., and Rouse, W. (197I). Ventricular endocardial potentials after experimental coronary artery occlusion in dogs. American Heart fournal, 82, 352.

Chatterjee, K., Sutton, G. C., and Miller, G. A. H. (1972). Right ventricular endocardial potential in acute massive pulmonary embolism. British Heart fournal, 34, 271.

Evans, G. L., and Glasser, S. P. (I97I). Intracavitary electrocardiography as a guide to a pacemaker positioning. Fournal of the American Medical Association, 216, 483.

Gordon, A. J., Vagueiro, M. C., and Barold, S. S. (1968). Endocardial electrograms from pacemaker catheters. Circulation, 38, 82.
Levine, H. D., Hellems, H. K., Dexter, L., and Tucker, A. S. (I949). Studies in intracardiac electrography in man. II. The potential variations in the right ventricle. American Heart fournal, 37, 64 .

Maekelt, G. A. (1960). Die Komplementbindungsreaktion der Chagaskrankheit. Zeitschrift für Tropenmedizin und Parasitologie, II, I52.

Requests for reprints to Dr. Orlando Gurdiel, Sección da Hemodinamic Hospital 'Dr. Miguel Perez Carreño' (I.V.S.S.), Caracas, Venezuela. 